\title{
INVESTIGATION OF BIVALVE MOLLUSCAN SEASHELLS FOR THE REMOVAL OF CADMIUM, LEAD AND ZINC METAL IONS FROM WASTEWATER STREAMS
}

\author{
Ch. Mahendra*, R.R. Sivakiran, K.A. Badrinarayana, Lakshmi Priya, \\ Shivani Raj and M. Mamatha \\ Department of Chemical Engineering, M.S. Ramaiah Institute of Technology, Bangalore, India \\ * E-mail: mahendra.ch6@gmail.com
}

\begin{abstract}
To treat industrial effluents containing heavy metals using low-cost materials, bivalve molluscans, a variety of seashells found in beaches were investigated for the sorption of heavy metals like cadmium $(\mathrm{Cd}), \mathrm{lead}(\mathrm{Pb})$, and zinc (Zn). The powdered seashells were characterized using SEM, FTIR and BET method. The accumulation of heavy metals on these bivalve seashells was found to be ion exchange. The equilibrium sorption capacity of seashell powder for $\mathrm{Pb}^{2+}, \mathrm{Cd}^{2+}$ and $\mathrm{Zn}^{2+}$ was determined to be $588.23,476.19$ and $357.14 \mathrm{mg} / \mathrm{g}$, respectively. Equilibrium sorption followed the Langmuir adsorption model. The optimum $\mathrm{pH}$ for the uptake of the studied heavy metals by the molluscan seashells was observed to be in the range of 5 to 7 . The sorption kinetics followed pseudo-secondorder kinetics. The values of enthalpy $\left(\Delta \mathrm{H}^{\circ}\right)$ and entropy $\left(\Delta \mathrm{S}^{\circ}\right)$ for the uptake of heavy metals were found to be negative which indicates the sorption to be an exothermic process and feasibility of sorption decreases with increasing temperature.
\end{abstract}

Keywords: Heavy Metal, Adsorption, Low-cost Materials

(C) RASĀYAN. All rights reserved

\section{INTRODUCTION}

The removal of heavy metals from the industrial effluents before disposal received much attention during recent times due to stringent rules for the protection of the environment. ${ }^{1}$ Some of the heavy metals like arsenic, mercury, cadmium, mercury, lead, etc are suspected to be carcinogens.

Flowing water streams or heavy rains can leach the heavy metals present in the earth's crust. Mineral processing operations also contribute to the leaching of heavy metals from ore and stockpiles. Electroplating industry discharging large volumes of metal-rich streams contaminate the water bodies in its proximity.

Cadmium, a toxic metal, is one of the main pollutants emanating from metal processing industries. ${ }^{2-4}$ Industrial effluents from lead battery production contain $\mathrm{Pb}^{2+}$ ions which are released at higher concentrations than the allowed permissible limit of $<1 \mathrm{ppm}$ for heavy metals. ${ }^{5}$ The nervous system is the most vulnerable target of lead poisoning. Zinc being the most widely used heavy metals in the electroplating industry leads to depression, lethargy, neurological signs, and increased thirst if present beyond 0.8 ppm in aqueous streams. ${ }^{6}$

Several methods like precipitation, ultrafiltration, ion exchange, electrochemical deposition, adsorption, etc., have been employed to treat aqueous waste streams containing heavy metals. ${ }^{7}$ Among all these methods, adsorption is simple and offers a greater advantage over other methods. Many low-cost biosorbents from agriculture and natural materials have been investigated in recent times for treating these toxic heavy metals. The use of natural materials for industrial effluent treatment has gained importance in recent times as they are cheap and easily obtained. ${ }^{8}$ The development of effective low-cost sorbents is still in search.

Seashells are the outer protective layer of a marine animal which is made out of several layers of proteins surrounded by calcite and platy calcium carbonate crystals layers. ${ }^{9}$

Rasayan J. Chem., 13(2), 903-914(2020)

http://dx.doi.org/10.31788/RJC.2020.1325617 
The main constituent of most of the seashells is $\mathrm{CaCO}_{3}$, which exists as calcite and aragonite forms. The surfaces of calcite and aragonite sorb manganese ions $\left(\mathrm{Mn}^{2+}\right)$ replacing $\mathrm{Ca}^{2+}$ on their surface. ${ }^{10,11}$ Several studies also showed that zinc too can be chemisorbed on calcite, dolomite, and magnesite surfaces. ${ }^{12}$ The mechanism of $\mathrm{Zn}^{2+}$ sorption on calcite was found to be ion exchange with $\mathrm{Ca}^{2+}$ on its surface. ${ }^{13} \mathrm{Cd}^{2+}$ removal using calcite showed that the uptake of $\mathrm{Cd}^{2+}$ was particle size-dependent. ${ }^{2}$ Oyster shells effectively removed copper and nickel ions from waste aqueous streams with uptake capacities of 49.26103.1 and $48.75-94.3 \mathrm{mg} / \mathrm{g}$, respectively. ${ }^{14,15}$ demonstrated that crab shells can sorb copper and cobalt on to their surface with maximum uptake capacities of 243.9 and $322.6 \mathrm{mg} / \mathrm{g}$, respectively. Dong S. Kim et a ${ }^{16}$ reported that crab shells treated with HCL were found effective in the removal of $\mathrm{Pb}^{2+}$ from aqueous waste streams. Crushed shells from the crab Scylla Serrata were able to remove 94.7 and $85.1 \% \mathrm{Cu}$ and $\mathrm{Cd}$, respectively from low concentrated solutions ${ }^{17}$. Waste mollusc and exoskeletons were used to reduce solutions of high $\mathrm{Pb}$ concentration to less than $0.5 \mathrm{ppm}$ in five minutes. ${ }^{18}$

In the present work, bivalve, a variety of molluscan seashell was investigated for the removal of heavy metals like $\mathrm{Cd}, \mathrm{Pb}$, and $\mathrm{Zn}$ from aqueous streams.

\section{Materials}

\section{EXPERIMENTAL}

The molluscan bivalve seashells used in the present study were procured from the local beaches of Mangalore in Karnataka. The shells were soaked in detergent water and then cleaned with demineralized water to remove the dirt adhered to it. These seashells were dried at $60^{\circ} \mathrm{C}$ in a hot air oven for 48 hours for the moisture to get completely removed. Later the shells were crushed to powder in a ball mill and separated according to different mesh sizes and stored. Seashell powder of 100 mesh size was chosen for different studies.

\section{Characterization}

The surface morphology of the seashell powder was characterized using a scanning electron microscope (SEM) - energy-dispersive X-ray (EDX), (Quanta 200). The functional groups of the seashells were determined using Fourier-transform infrared spectroscopy (FTIR) (Model-Bruker). BET surface area of the seashells was estimated using surface area analyzer (Smart Sorb 92/93) from Smart Instruments Company Pvt. Ltd.

\section{Equilibrium Isotherm Study}

To obtain equilibrium isotherms, $100 \mathrm{~mL}$ of a synthetic metal solution of $1000 \mathrm{ppm}$ was equilibrated with seashell powder of varying mass ranging from 0.1 to $0.5 \mathrm{~g}$. The experimental samples were left for $48 \mathrm{~h}$ to ensure equilibrium between sorbate and sorbent phases. After reaching equilibrium, the solution is filtered and centrifuged to separate shell powder from the metal ion solution. The metal ion concentration in the feed and the filtrate was determined using Atomic Absorption Spectrophotometer (AAS).

The uptake of different metal ions by the sorbent, $\mathrm{q}_{\mathrm{e}}(\mathrm{mg} / \mathrm{g})$, was obtained as follows:

$q_{e}=\frac{\left(c_{0}-c_{e}\right) v}{W}$

Where $C_{0}$ is the initial metal ion concentration in the feed solution and $C_{e}$ is the equilibrium concentration of the metal ion in the filtrate $(\mathrm{mg} / \mathrm{L})$, respectively; $\mathrm{V}$ is the volume of the solution employed $(\mathrm{L})$ and $\mathrm{W}$ is the mass of the sorbent $(\mathrm{g})$.

\section{Kinetic Study}

To determine the batch kinetics and equilibrium time for sorption, $200 \mathrm{mg}$ of seashell powder was added to $0.5 \mathrm{~L}$ of heavy metal ion solution of different concentrations. The solution was stirred at $500 \mathrm{RPM}$ using a mechanical stirrer to attain uniform concentration. Several samples were withdrawn from the bulk liquid to analyze the metal concentration in the bulk liquid. The batch kinetic studies were performed for different concentrations of metal ions at a $\mathrm{pH}$ of 6.5 . 
RASĀYAN J. Chem.

Vol. 13 | No. 2 |903 - 914| April - June | 2020

pH Study

The importance of $\mathrm{pH}$ of the aqueous solution on the accumulation of different heavy metals onto the surface of seashells was studied at different $\mathrm{pH}$ ranging 1 to 12 . Each metal ion $\left(\mathrm{Cd}^{2+}, \mathrm{Pb}^{2+}\right.$, and $\left.\mathrm{Zn}^{2+}\right)$ of $500 \mathrm{ppm}$ was adjusted for the desired $\mathrm{pH}$ using $\mathrm{HNO}_{3}$ and $\mathrm{NaOH}$. The metal solution $(100 \mathrm{~mL})$ was equilibrated with $0.2 \mathrm{~g}$ of shell powder for $3 \mathrm{~h}$ in an orbital shaker. After $3 \mathrm{~h}$, the filtrate was removed and analyzed for metal concentration using AAS.

\section{Temperature Study}

Temperature is one of the governing parameters in a sorption process. To study the effect of temperature on metal ion sorption onto the surface of seashells, each metal ion $(100 \mathrm{~mL})$ of 500 ppm was equilibrated with $0.2 \mathrm{~g}$ of seashell powder at different temperatures for $3 \mathrm{~h}$ in an orbital shaker.

\section{SEM-EDX}

\section{RESULTS AND DISCUSSION}

The SEM images of seashell powder before the sorption of heavy metals was shown in Fig.-1a. It was observed that the particles were distributed distinctly and no pores were observed. EDX analysis of the sorbent was also shown in Fig.-1b. The sorbent mainly consisted of carbon, oxygen, and calcium confirming the presence of calcium carbonate. The SEM images after the accumulation of cadmium, lead and zinc onto the seashell powder were shown in Fig.-2, 3 and 4.

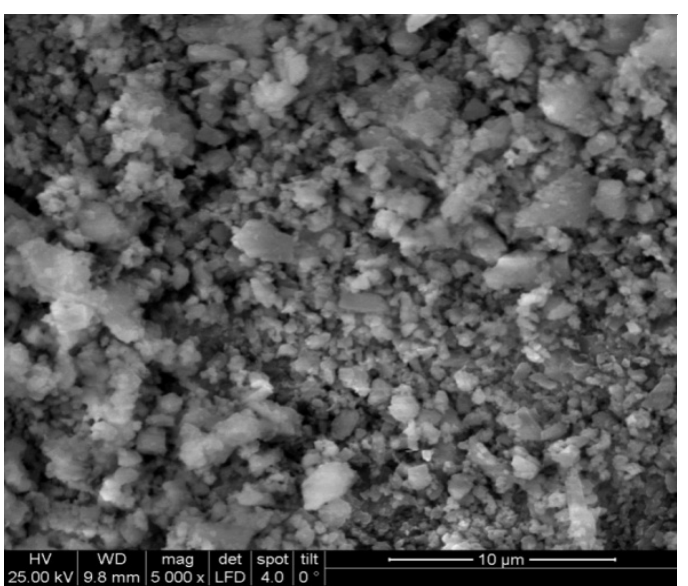

(a)

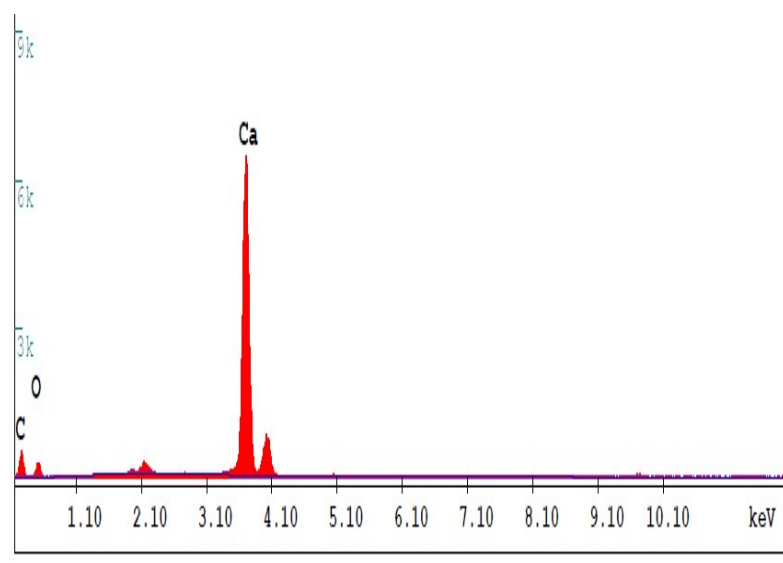

(b)

Fig-1: (a) SEM and (b)EDX Image of Seashell Powder

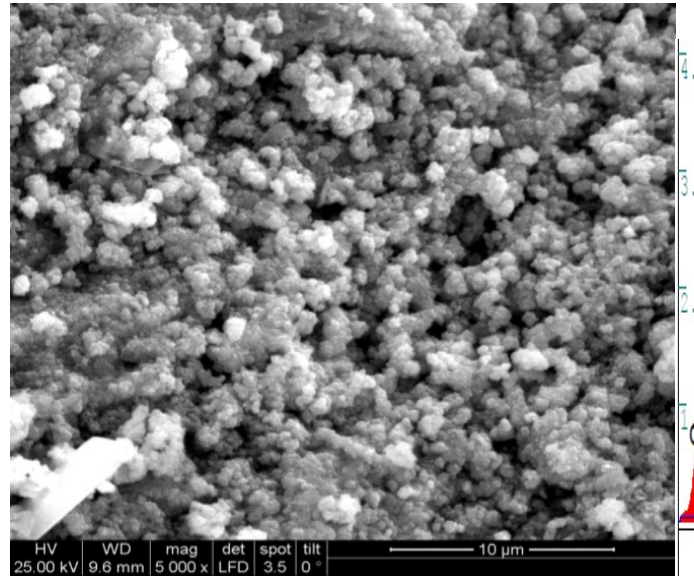

(a)

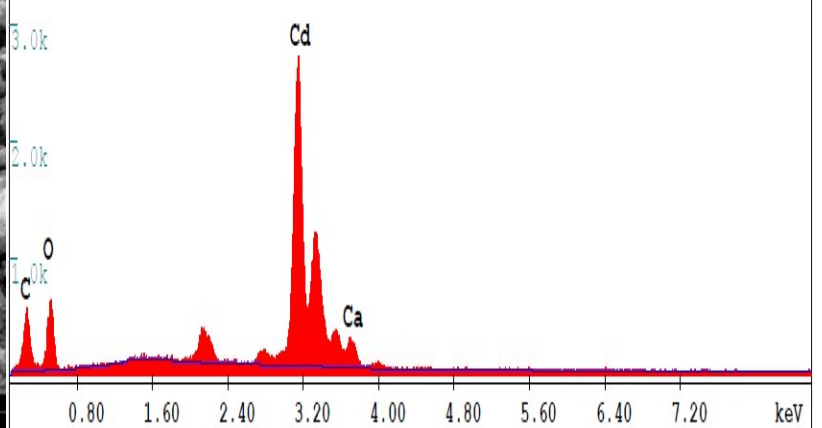

(b)

Fig.-2:(a) SEM (b)EDX Image of Seashell Powder after Cadmium Sorption 
RASĀYAN J. Chem.

Vol. 13 | No. 2 |903-914| April - June | 2020

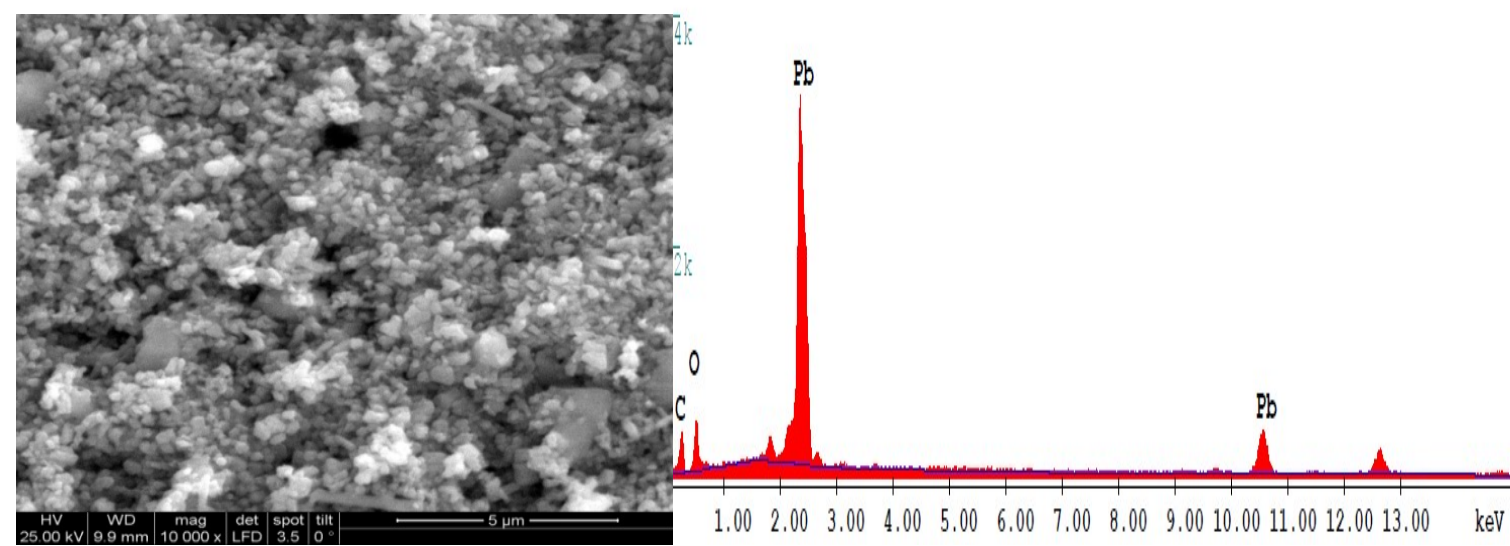

(a)

(b)

Fig.-3: (a) SEM (b) EDX Image of Seashell Powder after Lead Sorption

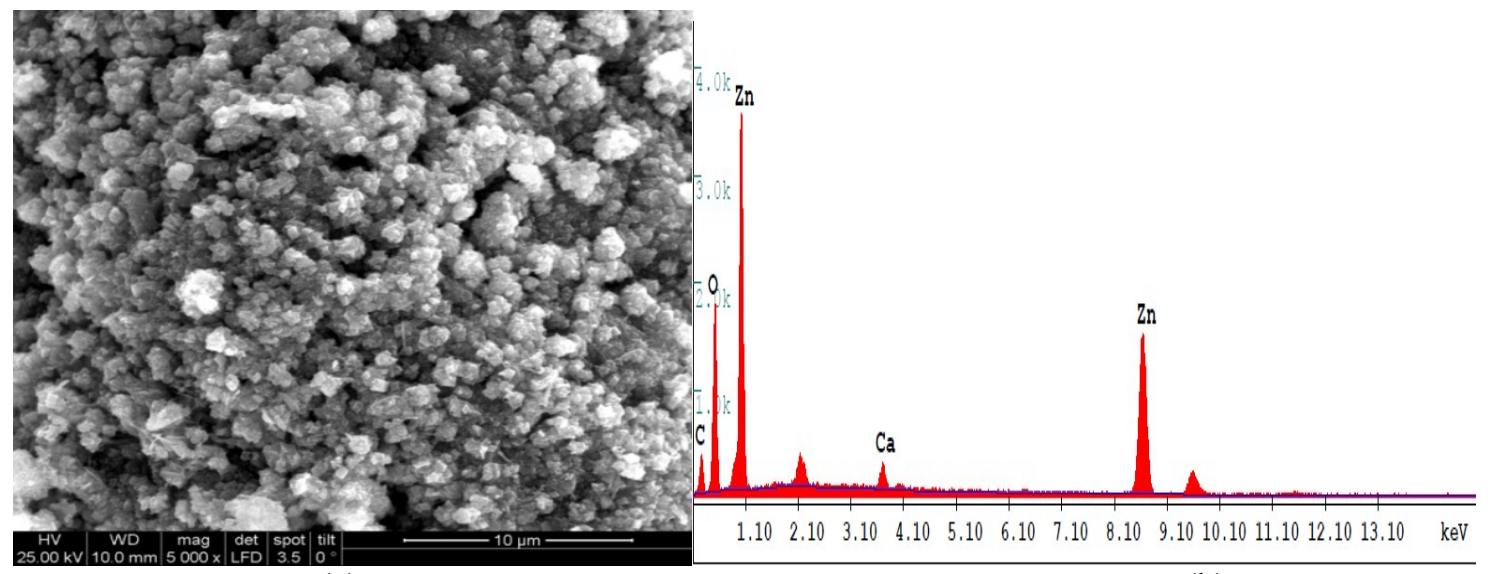

(a)

(b)

Fig.-4: (a) SEM (b) EDX Image of Seashell Powder after Zinc Sorption

Even after sorption, the particles were distributed distinctly. It was seen from Fig.-2b that most of the calcium was replaced by cadmium after equilibrating the metal solution with the seashell power. Similar profiles were observed for lead and zinc sorption also in Fig-3b and 4b, respectively where calcium content of the sorbent was negligible after the sorption of the heavy metals. EDX images shown in Fig.$2 \mathrm{~b}, 3 \mathrm{~b}$ and $4 \mathrm{~b}$ showed the replacement of calcium ions for the studied heavy metal ions (cadmium, lead and zinc). This confirmed the mechanism of the sorption of heavy metals onto the seashell powder to be ion exchange.

\section{FTIR}

The FTIR spectra of the seashell powder before and after sorption of different heavy metals were compared in Fig.-5. The FTIR spectra before and after the sorption of heavy metals showed discrete peaks at 712,980 and $1483 \mathrm{~cm}^{-1}$ which unveiled that $-\mathrm{CO}_{3}$ groups were the main constituents of molluscan seashells. ${ }^{11}$ Also, these strong peaks at $712 \mathrm{~cm}^{-1}$ and $1483 \mathrm{~cm}^{-1}$ indicated the presence of aragonite phase and calcite phases, respectively. ${ }^{11}$ Absorbance at $980 \mathrm{~cm}^{-1}$ was due to $\mathrm{C}-\mathrm{O}$ stretching vibrations which were not seen after the sorption of the heavy metals. Thus the FTIR analysis demonstrated the presence of $-\mathrm{CO}_{3}$ in the selected seashells which was found to interact with the heavy metal ions during its sorption on to the seashell powder.

\section{BET Surface Method}

The surface area of 100 mesh powder was determined using a surface area analyzer as $3.39 \mathrm{~m}^{2} / \mathrm{g}$ before the sorption of metal ions. After sorption, the surface area of seashell powder was found to be $0.22 \mathrm{~m}^{2} / \mathrm{g}$. 
RASĀYAN J. Chem.

Vol. 13 | No. 2 |903- 914| April - June | 2020

From the SEM image and the BET surface analysis, it can be inferred that the powder was not porous to provide high surface area. After sorption, the decrease in the surface area indicated that the sorption sites were blocked by the metal ions.

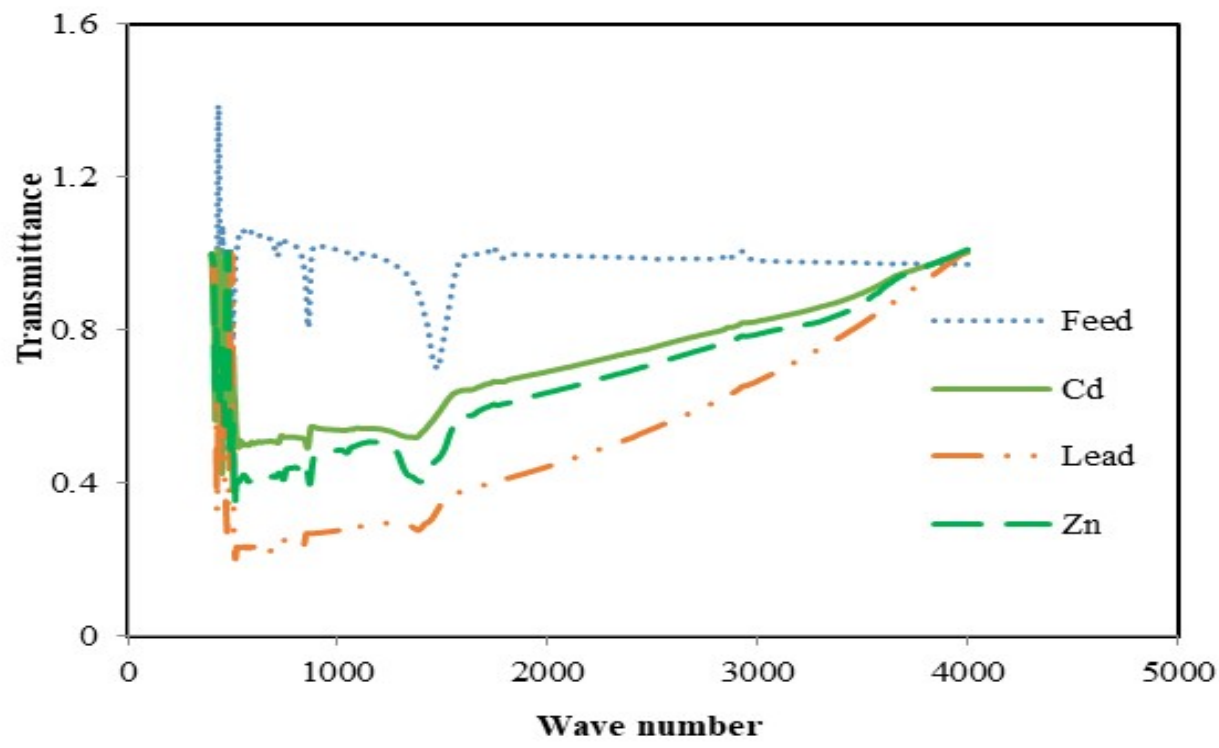

Fig.-5: FTIR Analysis of Seashell Powder before and after Sorption of Heavy Metals

\section{Equilibrium Isotherms}

The equilibrium uptake of different heavy metal ions $\left(\mathrm{Pb}^{2+}, \mathrm{Cd}^{2+}\right.$, and $\left.\mathrm{Zn}^{2+}\right)$ on to the surface of seashell powder was obtained and shown in Fig-6. Sorption capacities increased with a decrease in dose rate of sorbent and reached constant after a certain range. The maximum heavy metal uptake of seashell powder was obtained as $489 \mathrm{mg} / \mathrm{g}$ for $\mathrm{Pb}, 460 \mathrm{mg} / \mathrm{g}$ for $\mathrm{Cd}$ and $450 \mathrm{mg} / \mathrm{g}$ for $\mathrm{Zn}$ at $303 \mathrm{~K}$ and $\mathrm{pH} 6.5$.

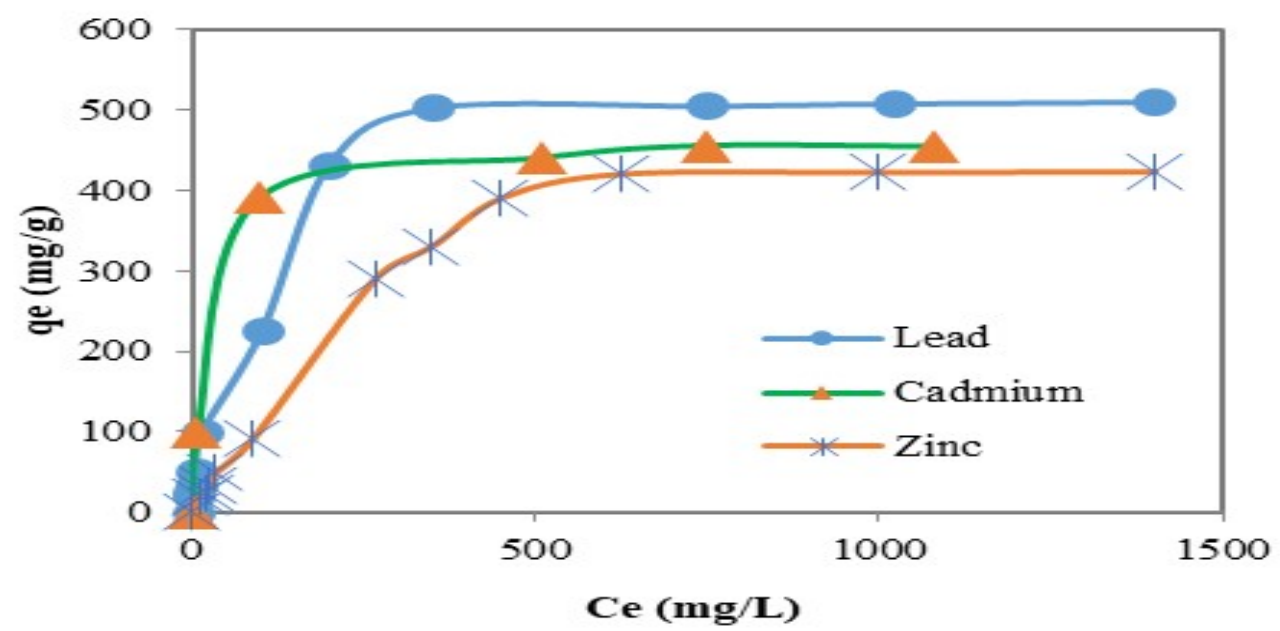

Fig.-6: Equilibrium Sorption Isotherms of $\mathrm{Pb}, \mathrm{Cd}$ and $\mathrm{Zn}$ Ions onto the Seashell Powder

Langmuir and Freundlich isotherm sorption models were fitted with experimental data to analyze the sorption type. The assumptions of the Langmuir model include a homogeneous surface with identical and unassociated sites distributed as a monolayer. The linearized Langmuir model equation is given by:

$$
\begin{aligned}
& \frac{q_{e}}{q_{m}}=\frac{K_{L} C_{e}}{1+K_{L} C_{e}} \\
& \frac{1}{q_{e}}=\frac{1}{q_{m}}+\frac{1}{q_{m} K_{L} C_{e}}
\end{aligned}
$$


RASĀYAN J. Chem.

Vol. 13 | No. 2 |903- 914| April - June | 2020

Where, $\mathrm{C}_{\mathrm{e}}=$ equilibrium metal ion concentration $(\mathrm{mg} / \mathrm{L})$ in the filtrate; $\mathrm{q}_{\mathrm{e}}=$ equilibrium metal ion concentration on sorbent or solid $(\mathrm{mg} / \mathrm{g}) ; \mathrm{q}_{\mathrm{m}}=$ maximum uptake of metal ion $(\mathrm{mg} / \mathrm{g})$ and $\mathrm{K}_{\mathrm{L}}$ is the Langmuir model constant.

Freundlich isotherm model assumes the adsorbent surface to be heterogeneous with sites distributed over multilayers. The linearized Freundlich model can be expressed as:

$$
\begin{aligned}
& q_{e}=K_{F} C_{e}^{1 / n} \\
& \operatorname{lnq}_{e}=\ln K_{F}+\frac{1}{n} \ln C_{e}
\end{aligned}
$$

$\mathrm{K}_{\mathrm{F}}\left(\mathrm{mg}^{1-1 / n} \mathrm{~L}^{1 / \mathrm{n}} / \mathrm{g}\right)$ and $\mathrm{n}$ are Freundlich constants. The value of $\mathrm{n}$ demonstrates the favourability of sorption. In general, the value of $\mathrm{n}$ ranging from 1 to 10 represents favorable sorption. The model constants, $\mathrm{K}_{\mathrm{F}}$, and $\mathrm{n}$ were estimated from the intercept and slope of the plot $\log \mathrm{q}_{\mathrm{e}} \mathrm{vs} \log \mathrm{C}_{\mathrm{e}}$.

From Table-1, it was confirmed that the uptake of heavy metal onto molluscan seashells followed the Langmuir isotherm model. It indicated that the molecules sorbed on the sorbent forms a monolayer of ions which do not interact or compete with each other.

Table-1: Equilibrium Isotherm Model Constants for Sorption of Heavy Metals onto the Seashell Powder

\begin{tabular}{c|c|c|c|c|c|c}
\hline \multirow{2}{*}{ Metal ion } & \multicolumn{3}{|c|}{ Langmuir constants } & \multicolumn{3}{c}{ Freundlich constants } \\
\cline { 2 - 7 } & $\mathrm{q}_{\mathrm{m}}$ & $\mathrm{b}$ & $\mathrm{R}^{2}$ & $\mathrm{~K}_{\mathrm{F}}$ & $\mathrm{n}_{\mathrm{F}}$ & $\mathrm{R}^{2}$ \\
\hline $\mathrm{Pb}$ & 588.23 & 0.013 & 0.987 & 6.48 & 2.73 & 0.972 \\
\hline $\mathrm{Cd}$ & 476.19 & 0.034 & 0.999 & 3.54 & 6.12 & 0.868 \\
\hline $\mathrm{Zn}$ & 357.14 & 0.004 & 0.960 & 1.72 & 1.43 & 0.991 \\
\hline
\end{tabular}

\section{Effect of Contact Time}

From Fig.-7, it was evident that the sorption of $\mathrm{Pb}^{+2}$ ions onto the seashells increased with contact time for different initial concentrations.

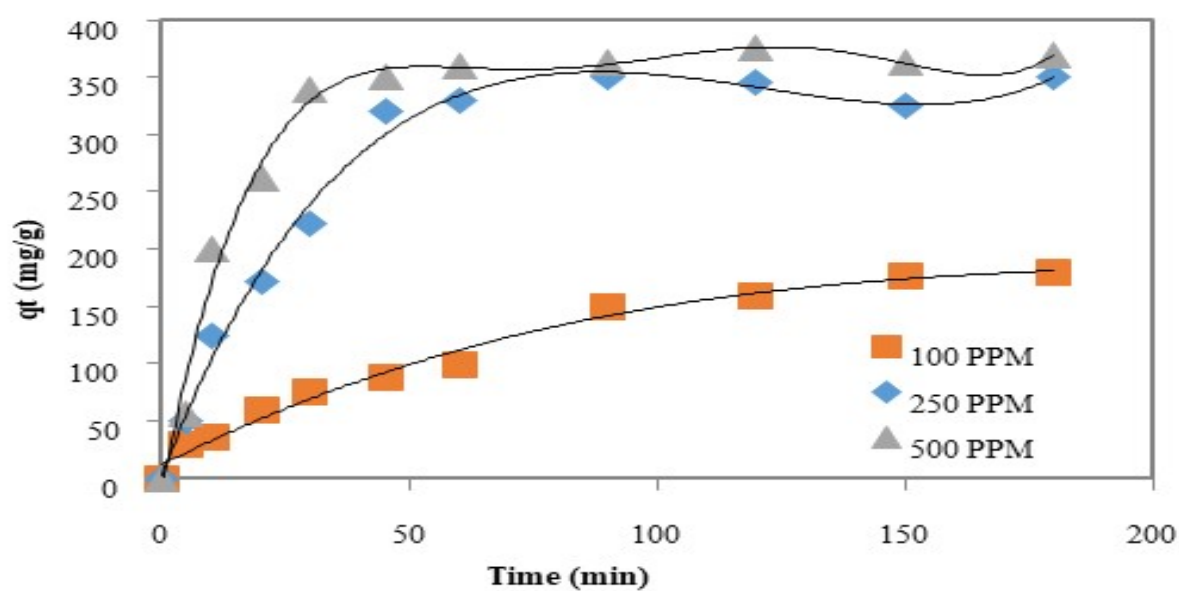

Fig.-7: Effect of Contact Time on Sorption of $\mathrm{Pb}$ by Seashell Powder

The uptake was rapid until 40 mins for all the concentrations studied and then slowly increased with time till 90 mins. After 90 mins, saturation was observed in the uptake capacity for all the initial concentrations. The saturation capacities were observed to be 180,350 and $370 \mathrm{mg} / \mathrm{g}$ for $\mathrm{Pb}$ ions onto the seashells for initial concentrations of 100, 250 and $500 \mathrm{mg} / \mathrm{g}$, respectively. From Fig.-8, the maximum uptake was determined for $\mathrm{Cd}$ ions onto the seashells to be $192.5,285$ and $314 \mathrm{mg} / \mathrm{g}$ for initial concentrations of 100, 250 and $500 \mathrm{ppm}$, respectively. Similarly from Fig-9, the maximum sorption capacity of $\mathrm{Zn}$ onto the seashells was seen to be 140,220 and $253 \mathrm{mg} / \mathrm{g}$. The equilibrium time was observed to be approximately 90 minutes for all the studied concentrations. 
RASĀYAN J. Chem.

Vol. 13 | No. 2 |903- 914| April - June | 2020

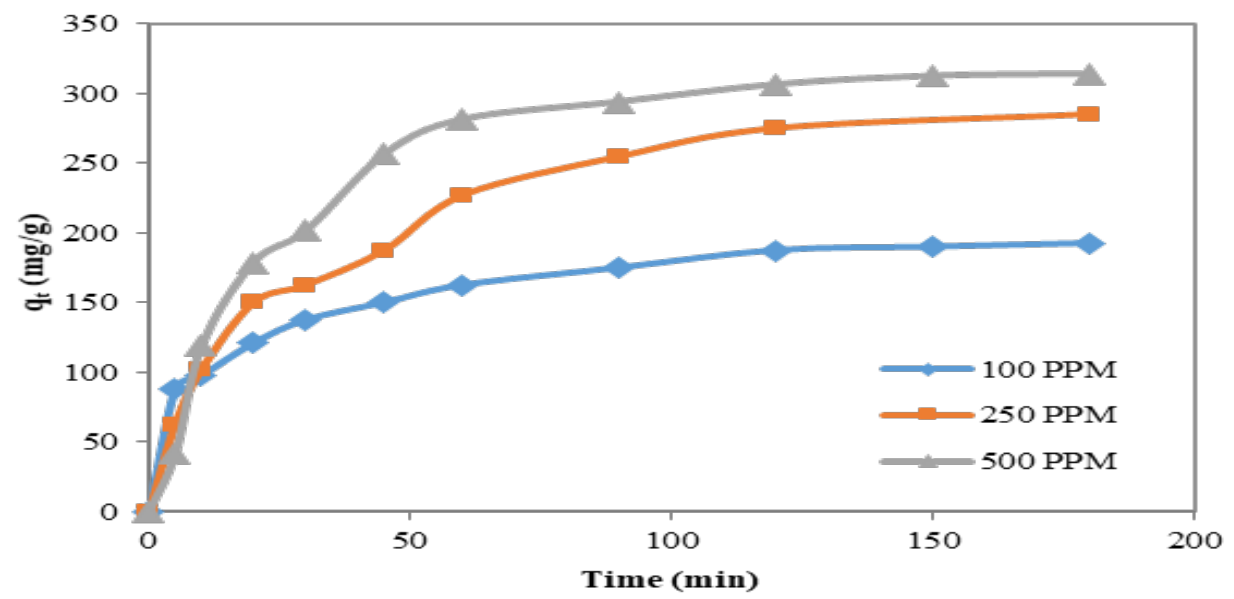

Fig.-8: Effect of Contact Time on Cd Sorption by Seashell Powder $(\mathrm{RPM}=400, \mathrm{pH}=6.5)$

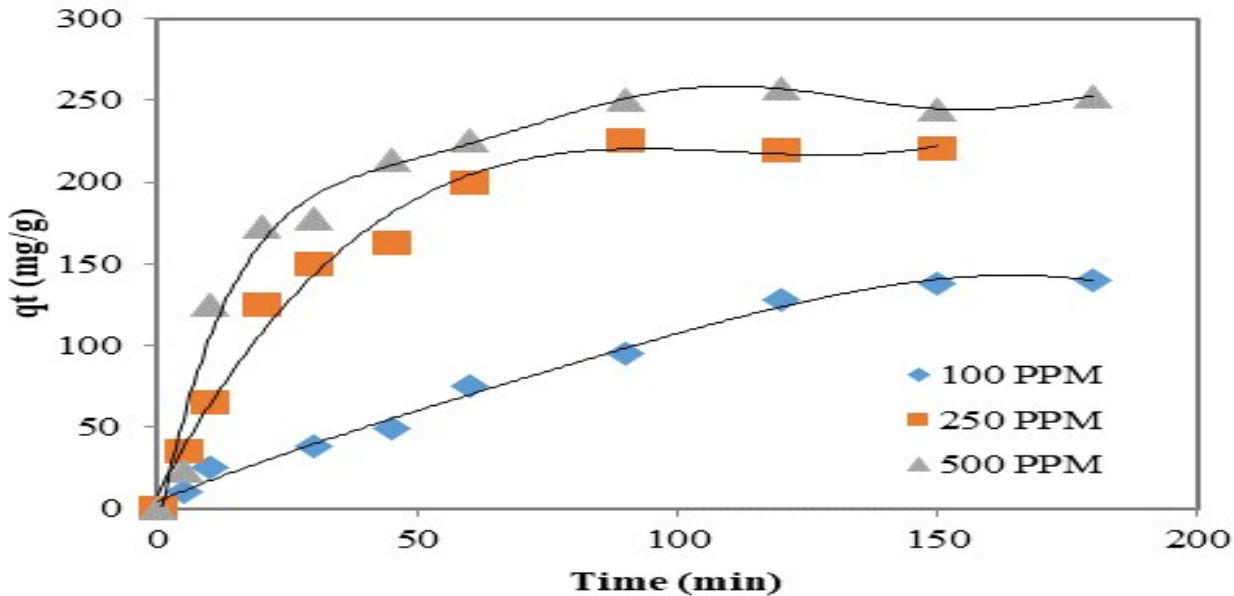

Fig.-9: Effect of Contact Time on Zn Sorption by Seashell Powder $(\mathrm{RPM}=400, \mathrm{pH}=6.5)$

The kinetics of sorption was determined using the batch kinetic data of different metal ions uptake by the seashell powder. The rate constants determine the uptake behavior of metal ions onto the solid surface and various kinetic models have been developed for analyzing the batch kinetic data. Lagergren model based on Pseudo-first-order kinetics and Ho model based on pseudo-second-order kinetics were examined to analyze the kinetics of sorption onto the seashells.

\section{Application of Kinetic Models}

Pseudo-first order Lagergren model

The mathematical expression of the Lagergren model $^{19}$ for sorption of adsorbate is given as:

$$
\frac{d q_{t}}{d t}=K_{1}\left(q_{e}-q_{t}\right)
$$

Where, $\mathrm{K}_{1}\left(\mathrm{~min}^{-1}\right)$ is the pseudo-first-order rate constant, $\mathrm{q}_{\mathrm{e}}(\mathrm{mg} / \mathrm{g})$ is the equilibrium concentration of adsorbate on the adsorbent and $\mathrm{q}_{\mathrm{t}}(\mathrm{mg} / \mathrm{g})$ is the uptake of adsorbate on to the adsorbent at any time.

The linearized Lagergren model is represented as:

$$
\ln \left(q_{e}-q_{t}\right)=\ln q_{e}-K_{1} t
$$

The constants $\left(K_{1}\right.$ and $\left.q_{e}\right)$ of the Lagergren model were determined from the plots of $\ln \left(\mathbf{q}_{\mathbf{e}}-\mathbf{q}_{\mathbf{t}}\right)$ vs $t$ for different parameters and were summarized in Table-2. 
RASĀYAN J. Chem.

Vol. 13 | No. 2 |903- 914| April - June | 2020

Pseudo-Second Order Model

The model expression of Ho and McKay ${ }^{20}$ is expressed as:

$\frac{d q_{t}}{d t}=K_{2}\left(q_{e}-q_{t}\right)^{2}$

The linear form of Eq. (8) can be written as:

$\frac{t}{q_{t}}=\frac{1}{K_{2} q_{e}{ }^{2}}+\frac{1}{q_{e}} t$

The pseudo-second-order rate constants $\left(\mathrm{K}_{2}\right)$ for the uptake of different metal ions onto the seashell powder were estimated from the plot of $t / q_{t}$ versus $t$ and tabulated in Table-2.

The Lagergren model equation did not fit the experimental kinetic data accurately. Even though the regression coefficient $\left(\mathrm{R}^{2}\right)$ of the fit was good for all the metals studied, the calculated $\left(\mathrm{q}_{\mathrm{th}}\right)$ and the experimental equilibrium uptake capacities $\left(\mathrm{q}_{\text {exp }}\right)$ evaluated using the linear Lagergren model varied widely. Thus the pseudo-first-order kinetic model was not suitable to describe the sorption kinetic mechanism of the studied heavy metals onto molluscan seashells. Further, the experimental kinetic data were tested for pseudo-second-order kinetics which showed a good fit with good regression coefficients $\left(\mathrm{R}^{2}>0.99\right)$. Further, the calculated $\left(\mathrm{q}_{\mathrm{e}}\right)_{\text {th }}$ values were also close to the experimental $\left(\mathrm{q}_{\text {exp }}\right)$ values for the three metals. So, it was deduced that the sorption of $\mathrm{Pd}, \mathrm{Cd}$ and $\mathrm{Zn}$ ions onto the molluscan seashells followed pseudo-second-order kinetics.

Table-2: Kinetic Model Constants for Sorption of Different Heavy Metal Ions

\begin{tabular}{c|c|c|c|c|c|c|c}
\hline \multirow{2}{*}{$\begin{array}{c}\text { Metal } \\
\text { Ion }\end{array}$} & $\begin{array}{c}\text { Conc. } \\
(\mathrm{mg} / \mathrm{L})\end{array}$ & \multicolumn{3}{|c|}{ First-order Kinetics } & \multicolumn{3}{c}{ Second-order Kinetics } \\
\cline { 3 - 8 } & & $\begin{array}{c}\mathrm{K}_{1} \\
\left(\mathrm{~min}^{-1}\right)\end{array}$ & $\begin{array}{c}\mathrm{q}_{\mathrm{e}} \\
(\mathrm{mg} / \mathrm{g})\end{array}$ & $\mathrm{R}^{2}$ & $\begin{array}{c}\mathrm{K}_{2} \times 10^{-5} \\
(\mathrm{~g} / \mathrm{mg} \cdot \mathrm{min})\end{array}$ & $\begin{array}{c}\mathrm{q}_{\mathrm{e}} \\
(\mathrm{mg} / \mathrm{g})\end{array}$ & $\mathrm{R}^{2}$ \\
\hline $\mathrm{Pb}$ & 100 & 0.009 & 8.57 & 0.930 & 14.01 & 238.09 & 0.955 \\
\hline & 250 & 0.016 & 11.07 & 0.940 & 11.68 & 400 & 0.981 \\
\hline & 500 & 0.020 & 11.82 & 0.897 & 16.13 & 454.54 & 0.984 \\
\hline $\mathrm{Cd}$ & 100 & 0.011 & 9.789 & 0.988 & 38.7 & 204.08 & 0.997 \\
\hline & 250 & 0.009 & 9.583 & 0.980 & 12.2 & 332.58 & 0.995 \\
\hline & 500 & 0.014 & 12.428 & 0.983 & 10.70 & 370.37 & 0.984 \\
\hline $\mathrm{Zn}$ & 100 & 0.010 & 10.145 & 0.891 & 2.91 & 250 & 0.819 \\
\hline & 250 & 0.017 & 10.175 & 0.938 & 13.70 & 270.27 & 0.987 \\
\hline & 500 & 0.025 & 10.99 & 0.958 & 11.78 & 312.50 & 0.916 \\
\hline
\end{tabular}

\section{Effect of pH}

$\mathrm{pH}$ is one of the significant parameters affecting the sorption of adsorbate onto the adsorbent. ${ }^{21}$ The surface charge of any sorbent can be influenced by affecting the $\mathrm{pH}$ of the surrounding solution. The $\mathrm{pH}$ of the feed solution was varied from 2 to 10 to find its effect on the accumulation of heavy metals onto the seashells. Sorption capacities of the studied heavy metals increased slightly with an increase in $\mathrm{pH}$ from 2 to 6 and then a decrease in accumulation of $\mathrm{Cd}$ and $\mathrm{Zn}$ was observed with further increase in $\mathrm{pH}$ as seen from Fig.-10.

The $-\mathrm{CO}_{3}$ groups of the molluscan seashells, as confirmed from the FTIR analysis, were easily protonated in acidic solutions $(\mathrm{pH}<4.0)$. The repulsion between $\mathrm{H}^{+}$ions and heavy metal ions might have resulted in lower uptake of metal ions in acidic solutions. Further, the sorbent was observed to dissolve in acidic conditions $(\mathrm{pH}<2)$ and no solid phase was seen for sorption. In the alkaline medium $(6<\mathrm{pH}<10),-\mathrm{CO}_{3}$ functional groups were negatively charged and the sorption of metal ions might be due to the attractive electrostatic forces between the sorbent surface and the metal ions. The increase in heavy metal sorption capacity in alkaline conditions resulted because of the reduced $\mathrm{H}^{+}$ions which competed with metals ions in acidic conditions for the active sites on the sorbent surface. ${ }^{22,}{ }^{23}$ For $\mathrm{pH}>10$, turbidity was observed in the metal solutions and even after equilibrating with shell powder, the precipitate was observed on the 
RASĀYAN J. Chem.

Vol. 13 | No. 2 |903- 914| April - June | 2020

walls of the container. The precipitation of metal ions might be due to the increased hydroxyl ions for $\mathrm{pH}$ $>10$ which might have reduced the sorption capacity of the shell powder.

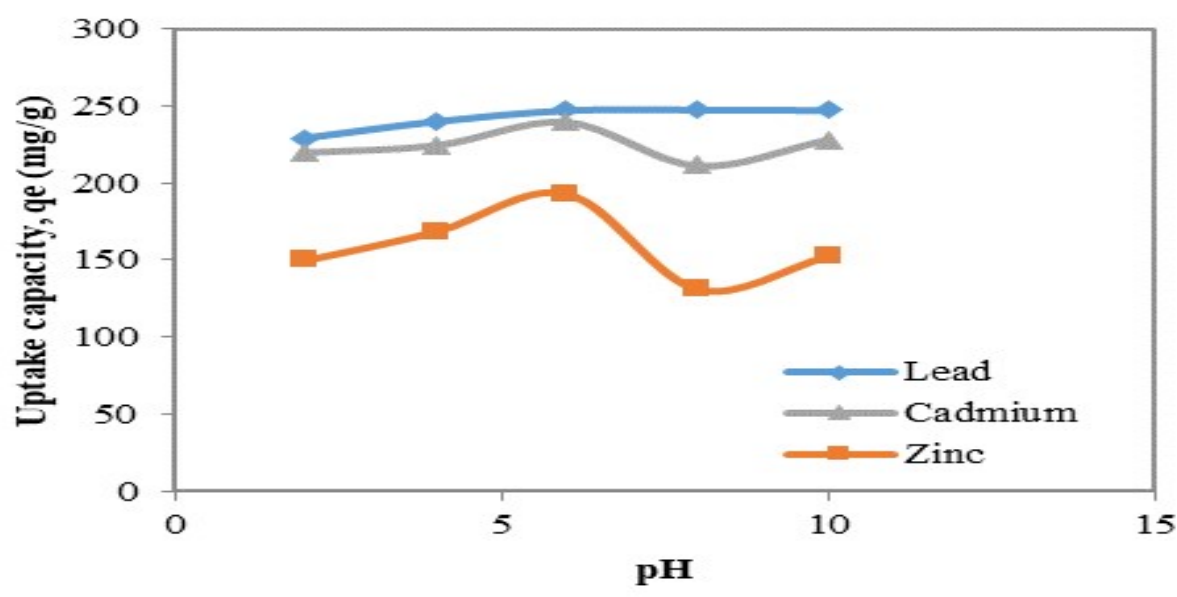

Fig.-10: Effect of $\mathrm{pH}$ on the Sorption of Different Heavy Metals onto the Seashell Powder

\section{Effect of Temperature}

The effect of temperature on heavy metal sorption by seashell powder was investigated in the range of 293 to $333 \mathrm{~K}$. The uptake of heavy metals by seashell powder was found to diminish with an increase in temperature (not shown) from 293 to $333 \mathrm{~K}$. The decrease in heavy metal uptake with temperature might be due to the weaker physical bonding between the heavy metal and the active sites of the sorbent at elevated temperatures. ${ }^{24}$ Also, as the solubility of metal ions increases with temperature, the solute prefers to be with the liquid phase than the solid phase. The decreased trend in heavy metal uptake capacity of seashell powder with temperature indicated that the sorption to be an exothermic process. ${ }^{25,26}$

The equilibrium constant $\left(K_{\mathrm{c}}\right)$ for the sorption of metal ions onto the solid phase was determined using equation (10). The free energy change $\left(\Delta \mathrm{G}^{\circ}\right)$ for the uptake of $\mathrm{Pb}, \mathrm{Cd}$, and $\mathrm{Zn}$ onto molluscan seashells at the studied temperatures was obtained by using equation (11) and were listed in Table-3, 4 and 5 respectively. Other thermodynamic properties like change in enthalpy $\left(\Delta H^{\circ}\right)$ and entropy $\left(\Delta S^{\circ}\right)$ were estimated from the linear plot of $\log \mathrm{K}_{\mathrm{c}}$ and $1 / \mathrm{T}$ as shown in Fig.-11.

$$
\begin{aligned}
& K_{c}=\frac{C_{S E}}{C_{l e}} \\
& \Delta G^{0}=-R T \log K_{c} \\
& \log K_{c}=\frac{\Delta S^{0}}{2.303 R}-\frac{\Delta H^{0}}{2.303 R T}
\end{aligned}
$$

Where, $C_{\mathrm{se}}$ and $C_{\mathrm{le}}$ are the equilibrium metal ion concentrations $(\mathrm{mg} / \mathrm{L})$ in the solid and liquid phases, respectively.

Table-3: Thermodynamic Parameters for Sorption of $\mathrm{Pb}$ onto the Seashell Powder

\begin{tabular}{c|c|c|c|c}
\hline Temp $(\mathrm{K})$ & $\log \mathrm{K}_{\mathrm{c}}$ & $\Delta \mathrm{G}(\mathrm{J} / \mathrm{mol})$ & $\Delta \mathrm{S}(\mathrm{J} / \mathrm{mol} \mathrm{K})$ & $\Delta \mathrm{H}(\mathrm{J} / \mathrm{mol})$ \\
\hline 293 & 3.9 & -9500.41 & & \\
\hline 303 & 3.45 & -8691.04 & \multirow{2}{*}{-78.790} & -44498 \\
\hline 313 & 3.3 & -8587.53 & & \\
\hline 333 & 2.9 & -8028.83 & & \\
\hline
\end{tabular}

Table-4: Thermodynamic Parameters for Sorption of Cd onto the Seashell Powder

\begin{tabular}{c|c|c|c|c}
\hline Temp $(\mathrm{K})$ & $\log \mathrm{K}_{\mathrm{c}}$ & $\Delta \mathrm{G}(\mathrm{J} / \mathrm{mol})$ & $\Delta \mathrm{S}(\mathrm{J} / \mathrm{mol} \mathrm{K})$ & $\Delta \mathrm{H}(\mathrm{J} / \mathrm{mol})$ \\
\hline 293 & 3.39 & -9500.41 & & \\
\cline { 1 - 3 } 303 & 2.8 & -8691.04 & \multirow{2}{*}{-78.79} & -44498 \\
\hline 313 & 2.6 & -8587.53 & & \\
\hline 333 & 2.5 & -8028.83 & & \\
\hline
\end{tabular}


RASĀYAN J. Chem.

Vol. 13 | No. 2 |903 - 914| April - June | 2020

Table-5: Thermodynamic Parameters for Sorption of $\mathrm{Zn}$ onto the Seashell Powder

\begin{tabular}{c|c|c|c|c}
\hline Temp $(\mathrm{K})$ & $\log \mathrm{K}_{\mathrm{c}}$ & $\Delta \mathrm{G}(\mathrm{J} / \mathrm{mol})$ & $\Delta \mathrm{S}(\mathrm{J} / \mathrm{mol} \mathrm{K})$ & $\Delta \mathrm{H}(\mathrm{J} / \mathrm{mol})$ \\
\hline 293 & 2.47 & -6016.92 & & \\
\hline 303 & 2.3 & -5794.03 & -72.204 & \multirow{2}{*}{-35211.6} \\
\hline 313 & 2.19 & -5699.00 & & \\
\hline 333 & 1.71 & -4734.24 & & \\
\hline
\end{tabular}

From Tables-3, 4 and 5, it was seen that the change in Gibbs free energy was negative at the studied temperatures which indicate that the sorption of heavy metals onto seashells is feasible and spontaneous. Further, the free energy change increased with temperature which proved that the sorption process was less favored at higher temperatures. The negative value of $\Delta \mathrm{H}^{\circ}$ indicates that the accumulation of heavy metals onto the seashell powder is exothermic and the negative value of $\Delta \mathrm{S} \circ$ is consistent with the sorbate and sorbent interactions.

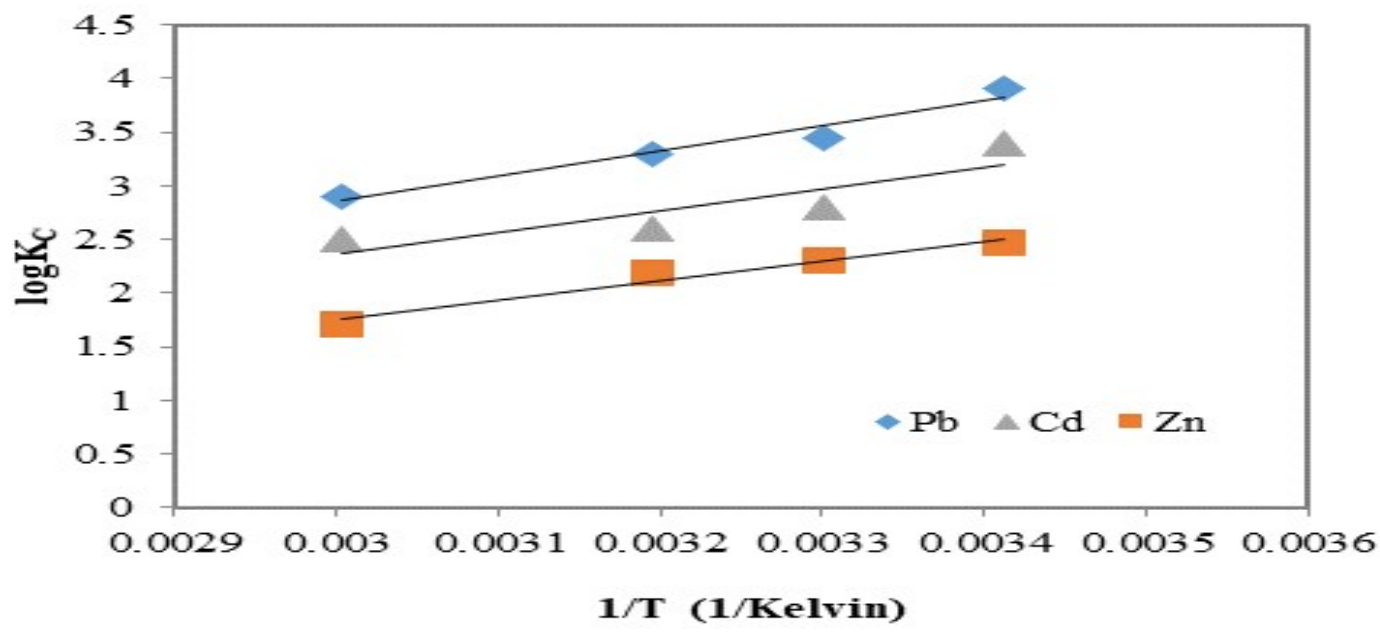

Fig.-11: 1/T Vs $\log \mathrm{K}_{\mathrm{c}}$ for Different Heavy Metals

\section{Comparison of Molluscan Seashells with Other Bio-sorbents}

The different metal ion uptake capacity of molluscan seashells was compared with various bio-sorbents and summarized in Table -6. It was seen that the molluscan seashells showed higher uptake capacity for heavy metals like $\mathrm{Cd}, \mathrm{Pb}$, and $\mathrm{Zn}$ than many other bio-sorbents. Low cost and easy availability of seashells were some of the attractive features of seashells powder for heavy metal removal from industrial effluents.

\begin{tabular}{c|c|c|c|c|c|c|c}
\multicolumn{8}{c}{ Table-6: Comparison of Sorption Capacities of Different Varieties of Seashells ${ }^{\mathbf{1 8 , 2 7}}$} \\
\hline S.No. & Metal & $\begin{array}{c}\text { Clam } \\
\mathrm{q}_{\mathrm{e}}(\mathrm{mg} / \mathrm{g})\end{array}$ & $\begin{array}{c}\text { Oyster } \\
\mathrm{q}_{\mathrm{e}}(\mathrm{mg} / \mathrm{g})\end{array}$ & $\begin{array}{c}\text { Lobster } \\
\mathrm{q}_{\mathrm{e}}(\mathrm{mg} / \mathrm{g})\end{array}$ & $\begin{array}{c}\text { Limestone } \\
\mathrm{q}_{\mathrm{e}}(\mathrm{mg} / \mathrm{g})\end{array}$ & $\begin{array}{c}\text { Chitosan } \\
\mathrm{q}_{\mathrm{e}}(\mathrm{mg} / \mathrm{g})\end{array}$ & $\begin{array}{c}\text { BIVALVES(Present Study) } \\
\mathrm{q}_{\mathrm{e}}(\mathrm{mg} / \mathrm{g})\end{array}$ \\
\hline 1 & $\mathrm{~Pb}$ & 1502.2 & 1502.2 & 1336.44 & 1502.2 & 617.456 & 588.23 \\
\hline 2 & $\mathrm{Cd}$ & 814.973 & 140.513 & 537.320 & 189.973 & 185.477 & 476.19 \\
\hline 3 & $\mathrm{Zn}$ & 467.253 & 463.985 & 352.890 & 463.985 & 341.880 & 357.14 \\
\hline
\end{tabular}

\section{CONCLUSION}

Bivalve Molluscan seashells have been investigated for the removal of different heavy metals $(\mathrm{Cd}, \mathrm{Pb}$, $\mathrm{Zn}$ ). The seashells were characterized using SEM-EDX, FTIR and BET surface methods to determine their surface morphology, composition, functional groups, and surface area. The surface area of 100 mesh powder was determined to be $3.39 \mathrm{~m}^{2} / \mathrm{g}$ before the sorption of metal ions. After sorption, the surface area of the seashell powder was reduced to $0.22 \mathrm{~m}^{2} / \mathrm{g}$. Form EDX analysis, the sorbent was found to be mainly composed of $\mathrm{CaCO}_{3}$. The sorption of heavy metals onto the surface of the seashells was due to the replacement of calcium ions which indicates the sorption mechanism to be ion-exchange instead of adsorption. The maximum uptake capacity of molluscan seashells was estimated as $588.23 \mathrm{mg} / \mathrm{g}$ for lead, 
RASĀYAN J. Chem.

Vol. 13 | No. 2 |903 - 914| April - June | 2020

$476.19 \mathrm{mg} / \mathrm{g}$ for cadmium and $357.14 \mathrm{mg} / \mathrm{g}$ for zinc at $303 \mathrm{~K}$ and $\mathrm{pH} 6.0$. The sorption mechanism of the studied metal ions onto the molluscan seashells was observed to follow Langmuir isotherm model assumptions. A contact time of 90 minutes was found to be sufficient to reach equilibrium for all the studied heavy metal sorption onto the seashells. The sorbent was found to be effective in the $\mathrm{pH}$ range of 6-8. Seashells were found to dissolve in highly acidic medium $(\mathrm{pH}<2)$. The kinetic data generated for different heavy metal sorption followed the pseudo-second-order kinetic model. The sorption capacity of the seashells for the heavy metals was comparable with the other materials available and hence it could serve as low-cost bio- sorbent for the heavy metals.

\section{REFERENCES}

1. S. Afroze and T. Kanti Sen, Water Air \& Soil Pollution, 229, 225(2018), DOI:10.1007/s11270-0183869-Z

2. Y. Du, F. Lian, and L. Zhu, Environmental Pollution, 159 (7), 1763(2011), DOI:10.1016/j.envpol.2011.04.017

3. L. Jarup and A. Akesson, Toxicology and Applied Pharmacology, 238(3), 201 (2009), DOI: 10.1016/j.taap.2009.04.020

4. Z. Wang, G. Huang, C. An, L. Chen and J. Liu, Desalination and Water Treatment, 57(47), 22493 (2016), DOI:10.1080/19443994.2015.1135084

5. S. Arulvel, A. Elayaperumal and M.S. Jagatheeshwaran, Journal of Environmental Chemical Engineering, 4(4), 3891 (2016), DOI:10.1016/j.jece.2016.08.031

6. C. Kumar Jain, D. Singh Malik, and A. Kumar Yadav, Environmental Processes, 3(2), 495 (2016), DOI: $10.1007 / \mathrm{s} 40710-016-0143-5$

7. Fu. Fenglian and Q. Wang, Journal of Environmental Management, 92(3), 407 (2011), DOI: 10.1016/j.jenvman.2010.11.011

8. A. P. Lim and A.Z. Aris, Reviews in Environmental Science and Bio/Technology, 13(2), 163(2014), DOI: $10.1007 / \mathrm{s} 11157-013-9330-2$

9. R. Narayanan, S. Dutta and S.K. Seshadri, Surface and Coating Technology, 200(16), 4720(2006), DOI: 10.1016/j.surfcoat.2005.04.040

10. K.Vijayaraghavan, H.Y.N.Winnie, R. Balasubramanian, Desalination, 266(1-3), 195(2011), DOI: 10.1016/j.desal.2010.08.026

11. M. Masukume, M.S. Onyango and J.P. Maree, International Journal of Mineral Processing, 133, 52(2014), DOI:10.1016/j.minpro.2014.09.005

12. J.J. Jurinak and N. Bauer, Soil Science Society of America Journal, 20(4), 466(1956), DOI: 10.2136/sssaj1956.03615995002000040006x

13. J.M. Zachara, J.A. Kittrick and H.B. Harsh, Geochimica et Cosmochimica Acta, 52(9), 2281(1988), DOI: 10.1016/0016-7037(88)90130-5

14. Hsu.Ting-Chu, Journal of Hazardous Materials, 171, 995(2009), DOI: 10.1016/j.jhazmat.2009.06.105

15. K. Vijayaraghavan, K. Palanivelu, and M. Velan, Bioresource Technology, 97(12), 1411 (2006), DOI: 10.1016/j.biortech.2005.07.001

16. D. S. Kim, Bioresource Technology, 94(3), 345(2004), DOI:10.1016/j.biortech.2003.10.030

17. A.Z. Aris, F.A. Ismail, H.Y. Ng, and S.M. Praveena, Pertanika Journal of Science and Technology, 22(2), 553 (2014).

18. H.E.A. Tudor, C.C. Gryte and C.C. Harris, Water Air and Soil Pollution, 173(1-4), 209 (2006), DOI: $10.1007 / \mathrm{s} 11270-005-9060-3$

19. S. Lagergren, Kungliga Svenska Vetenskapsakademiens Handlingar, 24, 1(1898).

20. Y. S. Ho and G. McKay, Process Biochemistry, 34(5), 451(1999), DOI:10.1016/S00329592(98)00112-5

21. Darjito, M. M. Khunur, D. Purwonugroho, M. A. Yuliantari, Z. R. Sari, L. H. A. K. Suryaningrat and Y. P. Prananto, Rasayan Journal of Chemistry, 12(3),1485(2019), DOI: 10.31788/RJC.2019.1235220 
RASĀYAN J. Chem.

Vol. 13 | No. 2 |903- 914| April - June | 2020

22. S. Chowdhury and P. Das, Separation Science and Technology, 46(12), 1966(2010), DOI: $10.1080 / 01496395.2011 .584930$

23. S. Chowdhury and P. Saha, Chemical Engineering Journal, 164(1), 168(2010), DOI: 10.1016/j.cej.2010.08.050

24. S. Rani, M. Bansal, K. Kaur and S. Sharma, Rasayan Journal of Chemistry, 12(3), 1247(2019), DOI:10.31788/RJC.2019.1235171

25. S. Rani, M. Bansal, K. Kaur and S. Sharma, Rasayan Journal of Chemistry, 12(3), 1315(2019), DOI:10.31788/RJC.2019.1235279

26. P. Das, J. Srivastava and S. Chowdhury, Journal of Water Reuse and Desalination, 3(2), 119(2013), DOI: $10.2166 / \mathrm{wrd} .2013 .070$

27. Z. Li, L. Li, D. Hu, C. Gao, J. Xiong, H. Jiang and W. Li, Journal of Colloid and Interface Science, 539, 400 (2019), DOI: 10.1016/j.jcis.2018.12.078

[RJC-5617/2019] 